\title{
Distribution and abundance of herbivorous grazing fishes in the central Great Barrier Reef. I. Levels of variability across the entire continental shelf ${ }^{\bullet}$
}

\author{
Garry Russ \\ Australian Institute of Marine Science, P. M. B. No. 3, Townsville M. C., Queensland 4810, Australia
}

\begin{abstract}
Visual censuses were used to study the distribution and abundance of herbivorous grazing fishes (Acanthuridae, Scaridae, Siganidae) on reefs in the central region of the Great Barrier Reef. Three locations on the continental shelf (inshore, mid-shelf, outershelf), 3 reefs within each of these locations and, for the mid-and outershelf reefs, 5 zones within each of these reefs were examined. The assemblages of herbivorous fishes on inshore reefs were distinctive from those on mid- and outershelf reefs, with significantly fewer numbers of species and individuals of acanthurids and scarids inshore. A major component of the variability in the data is a within-reef (between-zone) component. The within-reef component of variability, associated largely with differences in the assemblages with depth, is greater than that between mid- and outershelf locations and between reefs within these locations. When zones are examined individually and compared with reefs inshore the majority of species display significant cross-shelf change in abundance irrespective of the zone examined, with cross-shelf change accounting for often 80 to $90 \%$ of the variability in abundance. For most species much of this variability is due to an absence or low abundance on inshore reefs.
\end{abstract}

\section{INTRODUCTION}

The Great Barrier Reef (GBR) off the north-eastern coast of Australia comprises approximately 2,500 individual coral reefs (GBR Marine Park Authority, unpubl.). Until recently studies of the structure of communities of fishes on these reefs have been concentrated on only 3 reefs: Heron and One Tree Reefs in the southern GBR (approximately $23.5^{\circ} \mathrm{S}$ ) and Lizard Island Reef in the northern GBR (approximately $14^{\circ} \mathrm{S}$ ). Studies carried out in the central GBR near Townsville (approximately $19^{\circ} \mathrm{S}$ ) represent the first concentrated and coordinated attempt to characterize the broad scale patterns of distribution and abundance of coral reef fishes (Williams, 1982, 1983; Williams and Hatcher, 1983) and other biota (hard corals: Done, 1982; soft corals: Dinesen, 1983; calcified green algae: Drew, 1983). These studies have concentrated upon determining patterns of distribution and abundance of

- Contribution No. 245 from the Australian Institute of Marine Science organisms among reefs along a transect across the continental shelf from the mainland into the Coral Sea.

Williams (1982) and Williams and Hatcher (1983) concluded that there were significant changes in the structure of the communities of coral reef fishes along this cross-shelf transect. Their studies were carried out in only one reef zone, the windward reef slope. The aim of the present study is to determine whether crossshelf changes in community structure of a similar magnitude to those observed by Williams (1982) and Williams and Hatcher (1983) occur in other zones. A group of 51 species of herbivorous grazing fishes belonging to the families Acanthuridae, Scaridae and Siganidae was studied. These species comprise one of the more abundant groups of fishes on the study reefs, in terms of biomass and numbers (Williams and Hatcher, 1983) and their grazing activities on algal turfs contribute significantly to the tropho-dynamics of these coral reefs (e.g. Ogden and Lobel, 1978; Hatcher, 1982, 1983). This study addresses also the more general question: how does variability in the structure of assemblages of fishes within reefs compare with that 
between reefs at similar locations on the continental shelf and between reefs at different locations on the shelf? Patterns of zonation of herbivorous grazing fishes within reefs are described in greater detail in a companion paper (Russ, 1984).

\section{MATERIALS AND METHODS}

\section{Study sites}

The study was conducted on 9 reefs on the continental shelf in the central region of the Great Barrier Reef including the 8 studied by Williams (1982) (Fig. 1). Three reefs were located inshore, approximately $10 \mathrm{~km}$ from the coast (Pandora, Phillips, Lorne), 3 on the midshelf, approximately $50 \mathrm{~km}$ offshore (Rib, John Brewer, Lodestone), and 3 on the outershelf, approximately $100 \mathrm{~km}$ offshore (Myrmidon, Dip, Bowl). The gross morphology and environment of the study reefs have been described by Done (1982).

The areas studied within reefs are shown in Fig. 2. The inshore reefs were small and lacked the distinctive pattern of reef zonation of the mid- and outershelf reefs. Most of the perimeter of both Phillips and Lorne reefs and approximately one third of the perimeter of Pandora reef was censused and treated as one 'zone'. Depths of census dives varied from 3 to $8 \mathrm{~m}$ on these inshore reefs. The benthic communities consisted of macroalgae (Sargassum and Turbinaria) and the 'Porites massive/branched', 'Galaxea', 'Montipora' and 'Goniopora' coral communities described by Done (1982).

The reefs on the mid- and outershelf were larger than those inshore (Fig. 2) and displayed distinctive patterns of zonation (Done, 1982). Five zones were censused within each of the mid- and outershelf reefs: the windward reef slope, the windward reef crest, the reef flat, the lagoon and the back reef (Fig. 2). A brief description of each zone is given below and the locations of these zones are represented schematically in Fig. 3 of Russ (1984). All zones on the upper part of the reef (crest, flat, lagoon) were censused within $2 \mathrm{~h}$ either side of high tide. This was the only constraint placed upon the time of day when censuses were taken. Considerable effort was made to ensure that the physical characteristics of the areas censused for any particular zone were as comparable as possible for all mid- and outershelf reefs.

Windward reef slopes. All windward (south-east) reef slopes censused generally were steeply sloping, sometimes as steep as $70^{\circ}$. These slopes were censused at a depth of 12 to $15 \mathrm{~m}$, often just above the level where the steep slope plateaued onto more level areas of sand and rubble at 15 to $20 \mathrm{~m}$ depth. The southeastern faces of the outershelf reefs sloped away far more gently than those on the mid-shelf reefs and tended to lack a distinctive reef crest (see Fig. 5 of Done, 1982). To ensure that the reef slope (and reef crest) sites censused on the outershelf reefs were comparable to those censused on mid-shelf reefs, the northern flank of Myrmidon reef and the eastern flank of Dip reef were chosen for the reef slope (and reef crest) sites (Fig. 2). These areas corresponded closely with those studied by Williams (1982). The reef slope zone corresponds on the mid-shelf reefs to the 'Acropora splendida/divaricata' and 'Montipora/Pachyseris' coral communities, and on the outershelf to the 'Acropora palifera/Porites' coral community described by Done (1982). The percentage cover of soft corals was comparable to that of hard corals in this zone (Dinesen, 1983).

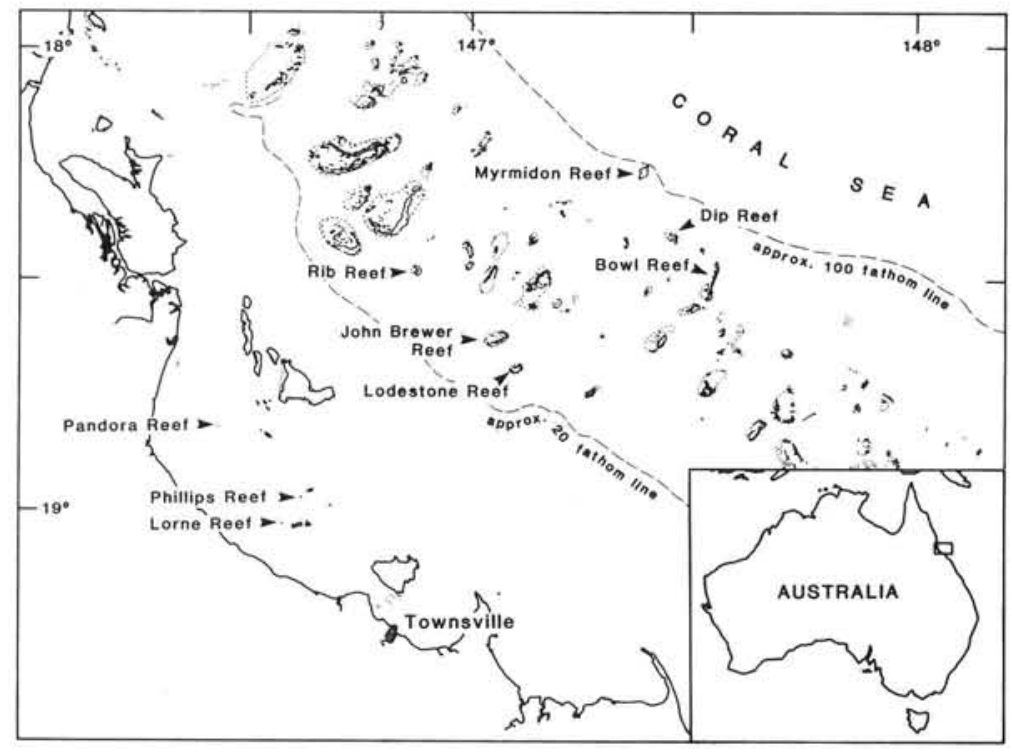

Fig. 1. Locations of study reefs in central Great Barrier Reef 
Fig. 2. Areas studied within mid-shelf and outershelf reefs and around the perimeter of inshore reefs. Each line shows the general area where 4 nonoverlapping replicate censuses were made on the respective reefs. (1) Reef slope, (2) reef crest; (3) reef flat; (4) lagoon; (5) back reef

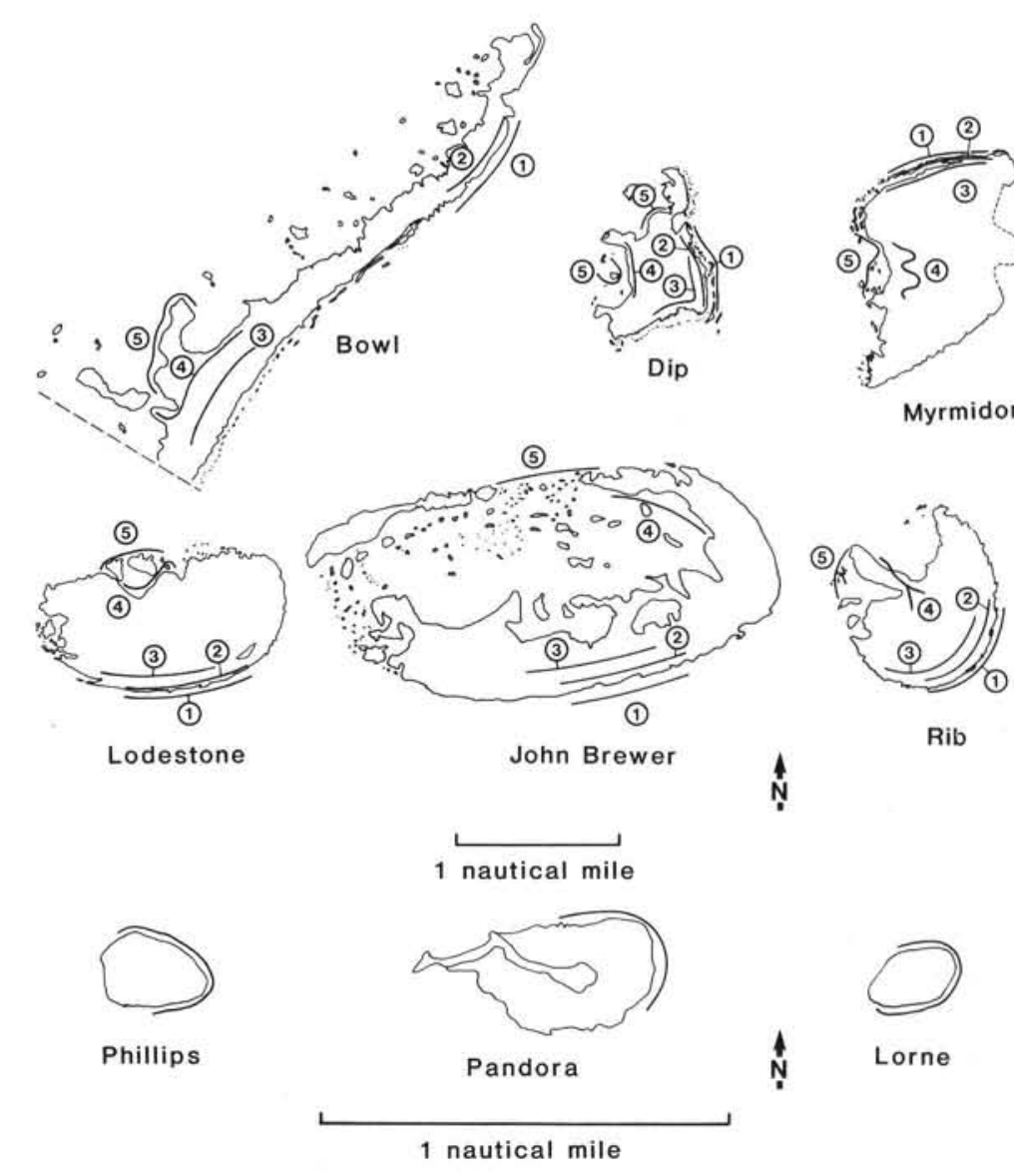

variant of the 'Acropora palifera/humilis' coral community (Done, 1982).

The lagoon. A complex combination of habitats was censused within this zone. An area typical of that censused consisted of flat-topped bombies (patch reefs) 5 to $20 \mathrm{~m}$ in diameter and 10 to $30 \mathrm{~m}$ apart, separated from each other by sand covered areas ( 50 to $90 \%$ sand cover) with a water depth of 3 to $7 \mathrm{~m}$. The tops of the bombies (depth approximately $2 \mathrm{~m}$ ) generally had a high percentage cover of live hard coral. The bases of the bombies and the sand covered areas often had staghorn Acropora thickets. This complex of tops and sides of bombies, sand covered areas and Acropora thickets constituted the 'lagoonal zone'. The tops of the bombies correspond to the 'Acropora tabulate/Faviid' coral community (Done, 1982) on the mid-shelf and the 'digitifera' variant of the 'Acropora palifera/humilis' coral community (Done, 1982) on the outershelf. The Acropora thickets in both mid- and outershelf lagoons correspond to the 'Acropora staghorn' coral community described by Done (1982). The exact areas censused on each reef are shown in Fig. 2.

Back reef. The bases of back reef bombies constituted the back reef zone. This zone was censused to a depth of 8 to $12 \mathrm{~m}$ and consisted of the bombie bases 'Isopora/Seriatopora' coral communities described by Done (1982) and on the outershelf the 'hyacinthus' 
together with the areas between bombies. The bombies were separated by areas with a cover of 30 to $70 \%$ sand. On the mid-shelf the coral communities of the back reef correspond to the 'Acropora splendida/ divaricata' and 'Porites massive/branched' ones described by Done (1982), while on the outershelf they correspond to the 'Porites/Diploastrea' community (Done, 1982). Soft corals were often almost as abundant as hard corals, a condition seen also on the deep windward reef slopes.

\section{Methods}

Three families, constituting the vast majority of species of large, herbivorous fishes on coral reefs of the Great Barrier Reef, were studied: Acanthuridae, Scaridae and Siganidae. A monospecific family placed previously within the Acanthuridae (Zanclidae) was included in the study also. A total of 51 species was chosen for detailed examination and each species was assigned to a feeding guild as defined by Hatcher (1983) (Table 1).
The assemblages of fishes were surveyed using a visual census technique similar to that used by Williams (1982). A census dive consisted of a $30 \mathrm{~min}$ swim (using SCUBA) through a zone recording the abundance of each species on a $\log 3$ abundance scale from 1 to 7 (Table 2). All individuals within approximately $5 \mathrm{~m}$ of either side of the diver were censused. The abundance of a species was recorded cumulatively throughout a census and all species were censused

Table 2. Numbers of individual fishes contained within each abundance category

\begin{tabular}{|cc|}
\hline $\begin{array}{c}\text { Abundance } \\
\text { category }\end{array}$ & $\begin{array}{c}\text { Number of } \\
\text { fishes }\end{array}$ \\
\hline 1 & 1 \\
2 & $2-3$ \\
3 & $4-9$ \\
4 & $10-27$ \\
5 & $28-81$ \\
6 & $82-243$ \\
7 & $244-729$ \\
\hline
\end{tabular}

Table 1. Species surveyed, feeding guild to which each was assigned, and their presence at particular locations on the continental shelf. Feeding guilds are: SS = sand sucker, SFS = sucker of fine sediments, SC $=$ small cropper, LC $=$ large cropper, $\mathrm{S}=$ scraper, $\mathrm{P}=$ planktivore, $\mathrm{SP}=$ sponge feeder, $\mathrm{C}=$ coral feeder. Locations are: $\mathrm{I}=$ inshore, $\mathrm{M}=$ mid-shelf, $\mathrm{O}=$ outershelf

\begin{tabular}{|c|c|c|c|c|c|}
\hline Species & $\begin{array}{l}\text { Feeding } \\
\text { guild }\end{array}$ & $\begin{array}{l}\text { Location } \\
\text { on shelf }\end{array}$ & Species & $\begin{array}{l}\text { Feeding } \\
\text { guild }\end{array}$ & $\begin{array}{l}\text { Location } \\
\text { on shelf }\end{array}$ \\
\hline ACANTHURIDAE & & & SCARIDAE & & \\
\hline Acanthurus dussumieri & SS & IMO & Scarus bleekeri & $\mathrm{s}$ & MO \\
\hline A. glaucoparieus & SC & MO & S. brevifilis & $\mathrm{s}$ & MO \\
\hline A. hepatus & SC & MO & S. dimidiatus & $\mathrm{s}$ & MO \\
\hline A. lineatus & LC & MO & S. flavipectoralis & SS? & MO \\
\hline A. 'mata' & SS & IMO & $S$. frenatus & $\mathrm{s}$ & MO \\
\hline A. nigricauda & SS & MO & S. ghobban & $\mathrm{s}$ & $\mathrm{IM}$ \\
\hline A. nigrofuscus & $\mathrm{SC}$ & MO & S. gibbus & $\mathrm{s}$ & IMO \\
\hline A. olivaceus & SS & MO & S. globiceps & $\mathrm{s}$ & IMO \\
\hline A. pyroferus & SC & $\mathrm{O}$ & S. niger & $\mathrm{s}$ & MO \\
\hline A. thompsoni & $\mathrm{P}$ & $\mathrm{O}$ & S. oviceps & $\mathrm{s}$ & MO \\
\hline A. triostegus & $\mathrm{SC}$ & MO & S. psittacus & $\mathrm{s}$ & MO \\
\hline A. xanthopterus & ss & $\mathrm{O}$ & S. rivulatus & $\mathrm{s}$ & IMO \\
\hline Ctenochaetus striatus & SFS & MO & S. rubroviolaceus & $\mathrm{s}$ & MO \\
\hline C. binotatus & SFS & MO & S. schlegeli & SS? & MO \\
\hline Naso annulatus & LC & MO & S. sordidus & $\mathrm{S}$ & IMO \\
\hline N. brachycentron & LC & $\mathrm{O}$ & S. spinus & $\mathrm{s}$ & MO \\
\hline N. brevirostris & LC & MO & S. sp. (c. f. lunula) & $\mathrm{s}$ & MO \\
\hline N. hexacanthus & $\mathrm{P}$ & 0 & Bolbometopon muricatus & $\mathrm{C}$ & MO \\
\hline N. lituratus & LC & MO & Cetoscarus bicolor & $\mathrm{s}$ & MO \\
\hline N. tuberosus & LC & MO & Hipposcarus longiceps & $\mathrm{s}$ & MO \\
\hline N. unicornis & LC & IMO & SIGANIDAE & & \\
\hline N. vlamingi & LC & MO & Siganus corallinus & LC & IMO \\
\hline Zebrasoma scopas & $\mathrm{SC}$ & MO & S. doliatus & LC & IMO \\
\hline \multirow[t]{2}{*}{$Z$. veliferum } & LC & MO & S. lineatus & LC & $\mathrm{IM}$ \\
\hline & & & $S$. puellus & LC & MO \\
\hline ZANCLIDAE & & & S. punctatus & LC & IMO \\
\hline Zanclus cornutus & SP & MO & S. vulpinus & LC & MO \\
\hline
\end{tabular}


simultaneously. Juveniles (less than 5 to $8 \mathrm{~cm}$ total length, depending upon the species) were not counted. The 30 min period was chosen on the basis of preliminary censuses of acanthurids in a variety of reef zones at various reefs. Number of species recorded was plotted against length of time of census with an asymptote being reached after approximately $30 \mathrm{~min}$. All data were recorded onto prepared census sheets of waterproof paper and all censuses were made by the author. Census dives for the reef slope, reef crest and reef flat were unidirectional and parallel to the reef crest while those for the lagoons and back reefs followed a meandering path between bombies. The distance covered by a census dive varied with conditions of wave surge and current but generally ranged between 300 and $400 \mathrm{~m}$, so that the area censused varied between approximately 3,000 and $4,000 \mathrm{~m}^{2}(300 \times 10 \mathrm{~m}$ and $400 \times 10 \mathrm{~m}$, respectively).

Four replicate, non-overlapping censuses were made once in each zone. Five zones were censused on each of the mid- and outershelf reefs and one 'zone' in each of the inshore reefs, making a total of 132 censuses. Censuses were carried out between July and October, 1982, with Lorne reef censused in February, 1983.

\section{Analysis of data}

The 132 censuses, including all 51 species, were subjected to an agglomerative, hierarchical classification (Williams, 1971). Bray-Curtis similarity coefficients (Bray and Curtis, 1957) were calculated between all 132 censuses, the 2 most similar censuses fused to form a cluster and the process repeated using Burr's incremental sum of squares strategy (Burr, 1970). The analysis was run using CSIRO's SAHN (ex-MULCLAS) program (Williams and Lance, 1977).

Cross-shelf trends in species richness and abundance are presented graphically. In all graphical presentations the most conservative estimate of abundance, the minimum number of individuals in an abundance category, was adopted. The minimum numbers of individuals per $\log 3$ abundance category are shown in Table 2. The abundance of a family in any one census is simply the minimum number of individuals per abundance category summed over all species in the family. The conservative presentation of abundance adopted here does not bias comparisons of abundance between zones, reefs or locations on the continental shelf.

Nested classification 1-factor analyses of variance were carried out upon the species richness and abundance category data. The fixed factor in the analysis, location upon the continental shelf, has 3 levels:
Inshore, Mid-shelf and Outershelf. Three reefs are nested within each of these levels and an analysis was carried out for each zone separately. There were 4 replicate censuses made in each zone so that each nested classification 1 -factor analysis of variance had 35 degrees of freedom. The inshore reefs lacked the distinct zonation of the reefs on the mid- and outershelf. It was considered that the most efficient method of comparing between shelf locations was to use the same set of data from the inshore reefs in a series of analyses for each separate zone. This approach seemed preferable to combining the data for all zones for each mid- and outershelf reef. The use of abundance categories (or in the case of a family, abundance categories summed over all species in the family) in an analysis of variance is justified on the basis that it is approximately equivalent to carrying out the analysis on log-transformed actual counts of individuals. Homogeneity of variance $(p=.01)$ for all analyses was determined using Cochran's test (Winer, 1971). In 2 of 15 analyses of species richness the data were transformed to $\log _{10}(x+2)$ to overcome heterogeneity of variances. Variances were heterogeneous in 3 of 9 analyses of abundance of individual species. A major cause of this significant heterogeneity was the frequent total absence of species on reefs, usually the inshore reefs. Analyses were carried out in these cases if the calculated Cochran's value did not exceed the tabulated value for the number of treatments (reefs) where the species in question was present. Multiple comparisons of means (at a significance level of $\mathrm{p}=.01$ ) for each location on the shelf were carried out using the Student-Newman-Keuls (SNK) procedure (Winer, 1971). The percentage of the variability in the data accounted for by cross-shelf differences (the variance component) was calculated according to the procedure of Sokal and Rohlf (1969, p. 263) and is presented with the results of the multiple comparisons.

\section{RESULTS}

Fig. 3 is a dendrogram generated from the classification analysis. Each split of this dendrogram results in 2 groups which are significantly different from one another (Test of Sandland and Young, 1979a, b). The first split in the data set places all censuses from inshore reefs in a group distinct from all censuses from mid- and outershelf reefs. The mid- and outershelf reefs split into a group containing all censuses from the deep zones (reef slope, back reef) and another containing all censuses from the shallow zones (reef crest, reef flat, lagoon). Censuses from the deep zones split into a group containing all censuses from the mid-shelf reef slopes and back reefs, and another containing all cen- 
suses from the outershelf reef slopes and back reefs (Fig. 3). The analysis did not differentiate between reef slope and back reef censuses on the mid-shelf reefs. There is a statistically significant split on the outershelf into a group containing all censuses from the back reefs of Dip and Bowl reefs and a group containing all censuses from the outershelf reef slopes plus the back reef of Myrmidon reef (not shown in Fig. 3).

Censuses from the shallow zones split into a group containing all censuses from reef flats (with the exception of all 4 censuses from Myrmidon reef flat) and one

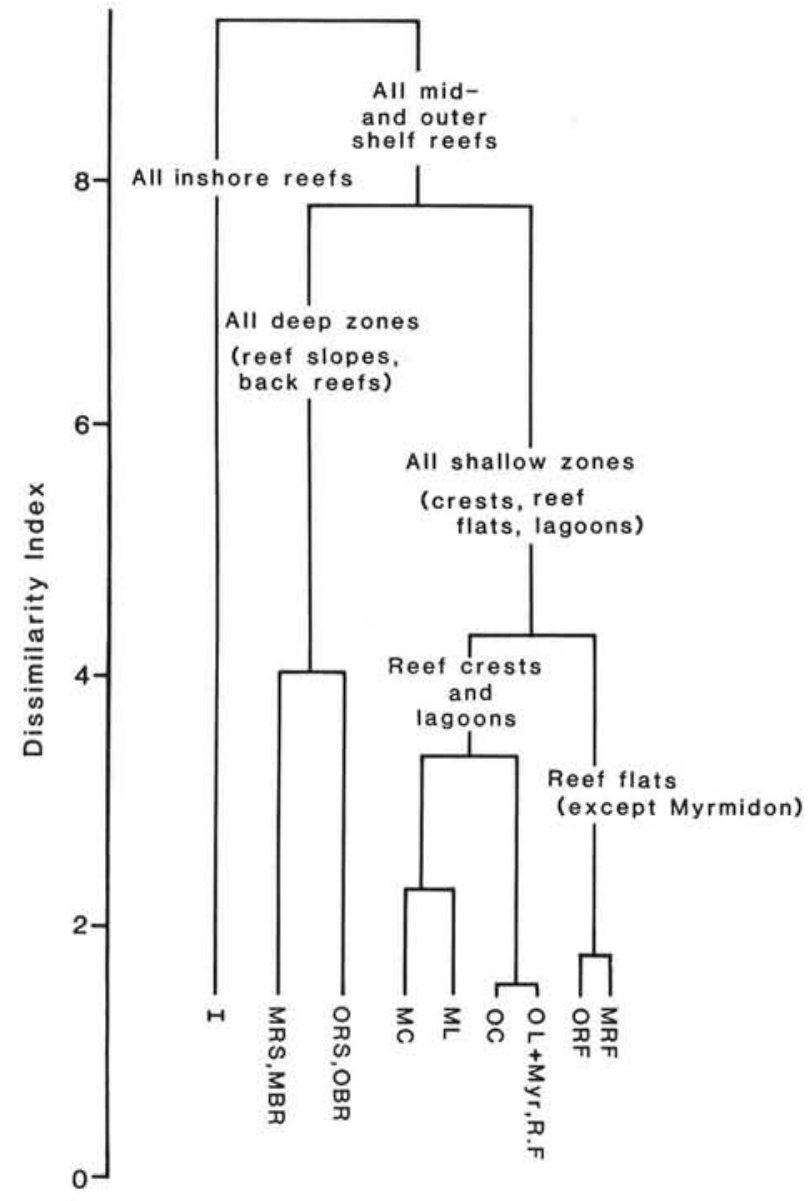

Fig. 3. Dendrogram from classification analysis of 132 censuses. I: Inshore, M: mid-shelf, O: outershelf, RS: reef slope,

C: reef crest, RF: reef flat, L: lagoon, BR: back reef

containing all censuses from the reef crests and lagoons (plus Myrmidon reef flat) (Fig. 3). The latter group splits into a group containing all the mid-shelf censuses and another containing all the outershelf censuses. The mid-shelf censuses split into a group containing all censuses from crests and another containing all censuses from lagoons (Fig. 3). The outershelf censuses split into a group containing all censuses from crests and another containing all censuses from lagoons plus those from the reef flat of Myrmidon reef (Fig. 3). The reef flats split into a group containing all censuses from mid-shelf reef flats and another containing all censuses from the reef flats of Dip and Bowl reefs (Fig. 3).

Of the 51 species studied 12 were recorded inshore, 46 on the mid-shelf and 49 on the outershelf (Table 1). All species recorded inshore occurred on the mid-shelf and 10 of these 12 occurred on the outershelf also. A total of 44 species were shared between mid- and outershelf locations. All species not shared between these locations were recorded rarely in the locations in which they occurred. Thus the species compositions of the assemblages of large, herbivorous fishes were very similar on mid- and outershelf reefs, with very few species recorded inshore.

Fig. 4 and 5 show respectively the cross-shelf changes in mean number of species and abundance of individuals per census ( $\pm 95 \%$ confidence limits) for each family of herbivorous fishes and for each zone. Note that one 'zone' only was sampled on inshore reefs so that the same set of data from the inshore reefs is presented in each histogram for each separate zone in Fig. 4 and 5. Cross-shelf differences account for a very high percentage of the variability in the data sets for the acanthurids and scarids but much less so for the siganids in all zones. Species richness and abundance always were significantly greater on mid- and outershelf reefs than on inshore reefs for both the acanthurids and scarids. Acanthurids had a greater species richness on outershelf than on mid-shelf reefs in all zones but this difference was significant (at $p=.01$ ) for the reef slopes and reef flats only (Fig. 4). A more comprehensive analysis of this data (Russ, 1984) which excluded the inshore reefs showed that the trend of increasing species richness of acanthurids from mid- to outershelf reefs is understated by the Student-Newman-Keuls results presented in Fig. 4. Acanthurids were significantly more abundant on outershelf than mid-shelf reefs in all zones but the reef crest (Fig. 5). There were no significant differences in species richness or abundance of scarids between mid- and outershelf reefs for any zone. There were no significant differences in species richness or abundance of siganids across the whole continental shelf for all zones but an analysis of this data which excluded the inshore reefs (Russ, 1984), showed a significantly higher species richness and abundance of siganids on the mid-shelf than on the outershelf reefs.

When zones were examined individually and compared with reefs inshore the majority of species displayed significant cross-shelf change in abundance irrespective of the zone examined, with cross-shelf change accounting for often 80 to $90 \%$ of the variability in abundance. For most species much of this variability was due to an absence or low abundance on inshore reefs. Fig. 6 provides examples of such cross- 

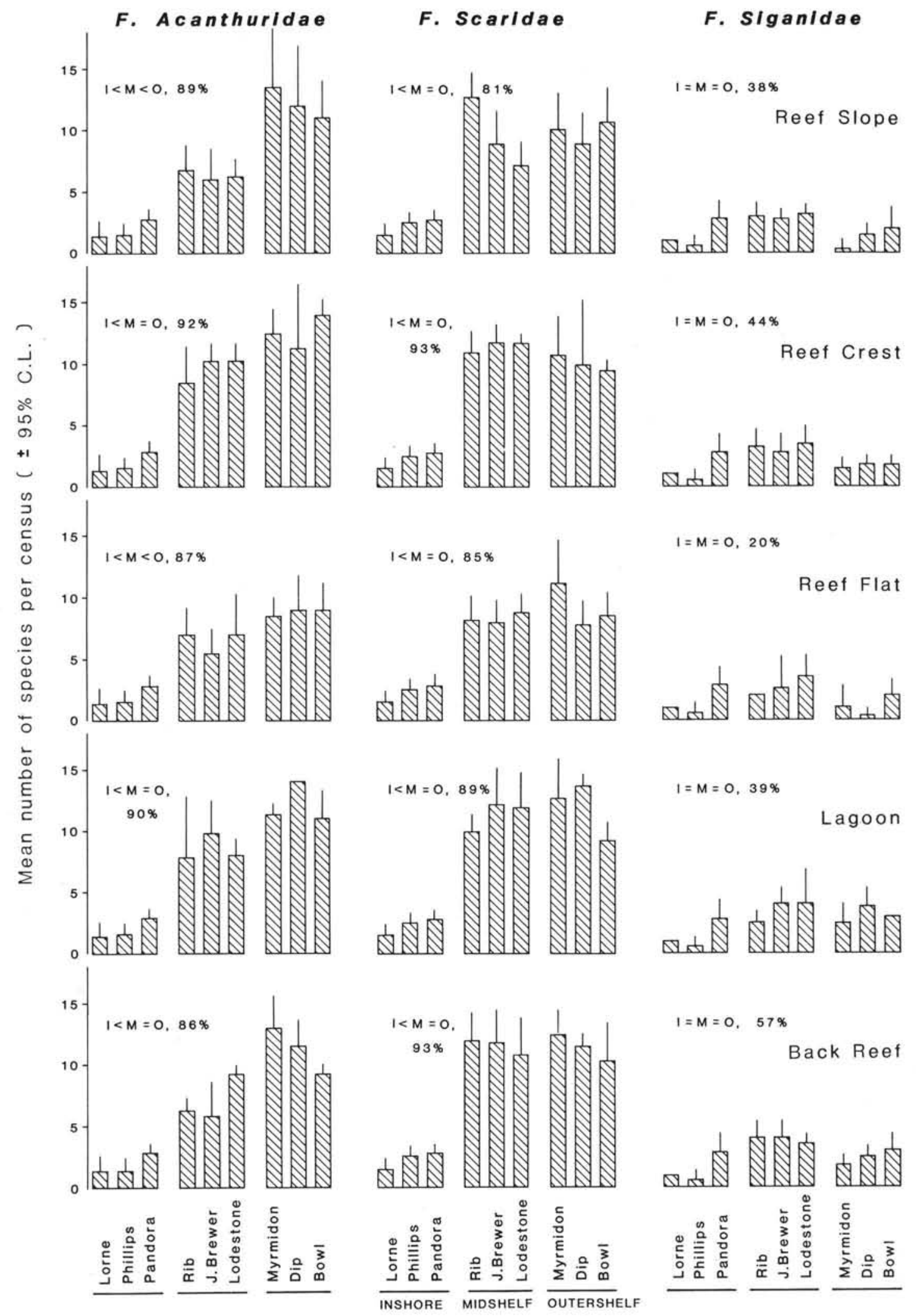

Fig. 4. Cross-shelf changes in mean number of species per census ( $\pm 95 \%$ confidence limits) for 3 families of herbivorous fishes in each of 5 zones. A nested classification 1-factor analysis of variance was performed for each family and zone. Percentage of variability accounted for by cross-shelf change (variance component) is shown, together with the result of SNK a posteriori comparison of means. I: inshore, M: mid-shelf, O: outershelf 
${ }^{200}$ F. Acanthurldae

$1<M<0,90 \%$
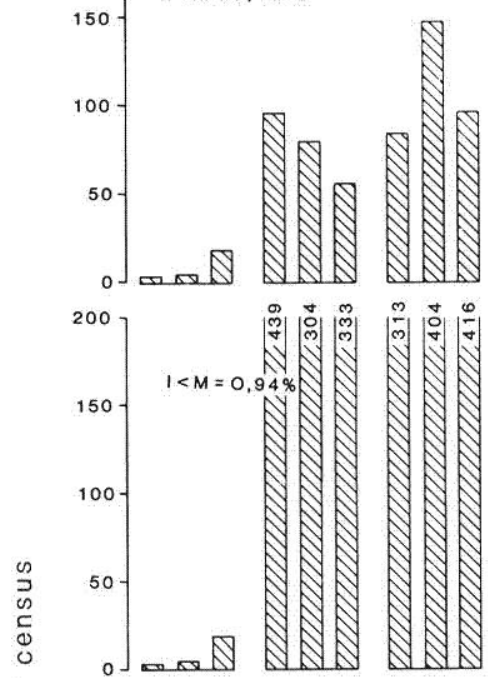

产 200

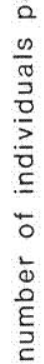

$E$
E
$\frac{E}{E}$
ह
ฮ
$\Sigma$
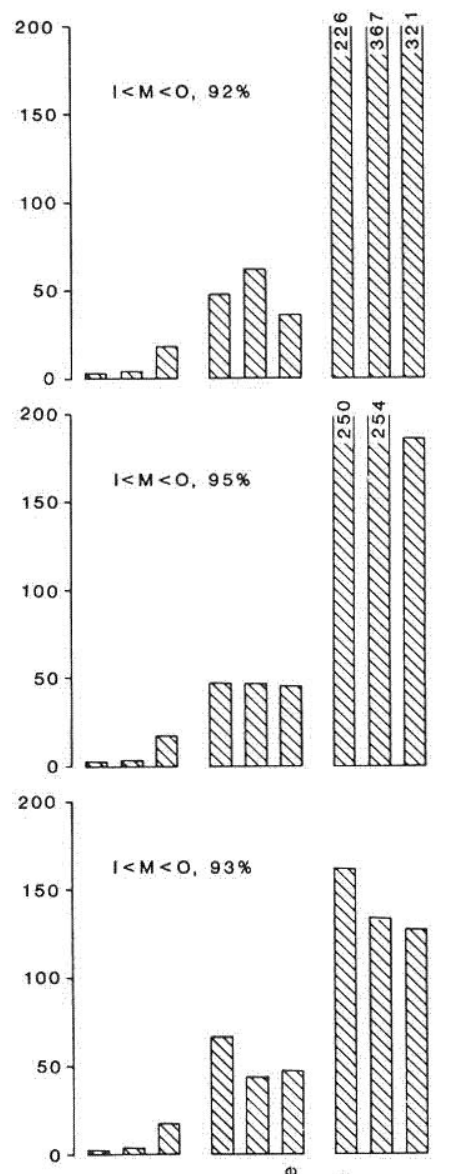

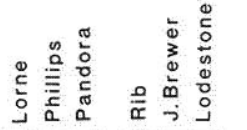

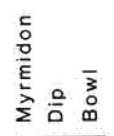

F. Scaridae

$1<M=0,84 \%$
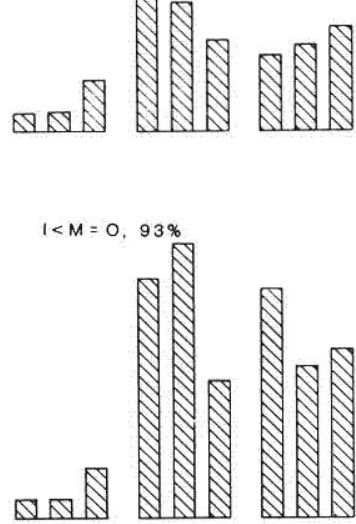

$1<M=0,85 \%$
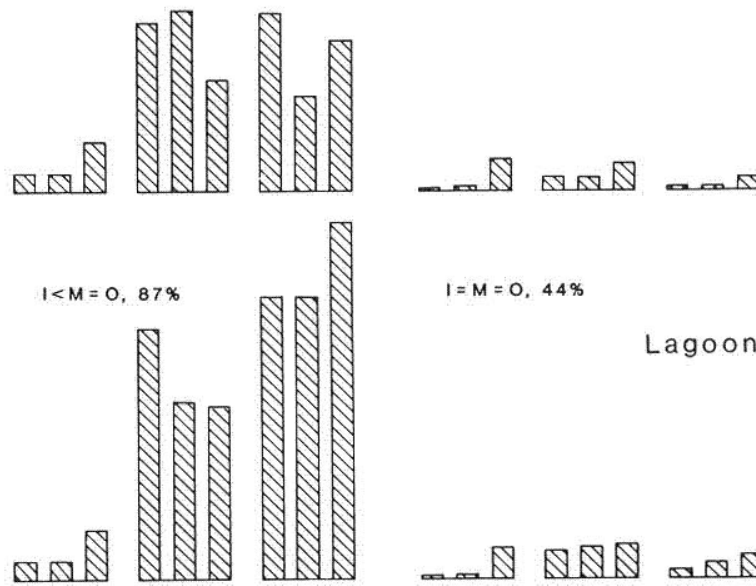

$1<\mathrm{M}=0,95 \%$
$I=M=0,21 \%$

Reef Flat

$I=M=0,44 \%$

Lagoon

$\mathrm{I}=\mathrm{M}=0,38 \%$

Back Reef

Reef Crest

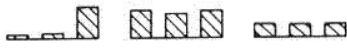

$\begin{array}{ll}-\infty & \mathbb{Q}\end{array}$

$-\mathbb{N} \mathbb{N}=\mathbb{N}$

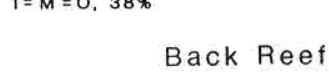

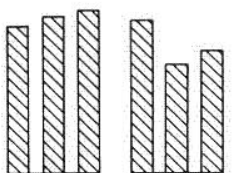

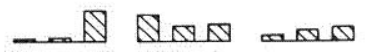

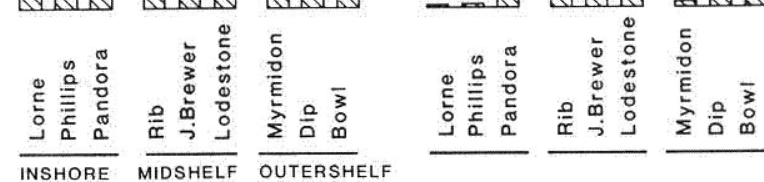

Fig. 5. Cross-shelf changes in mean minimum number of individuals per census for 3 families of herbivorous fishes in each of 5 zones. Results of nested classification 1-factor analyses of variance on the abundance categories summarized as in Fig. 4 
shelf comparisons in abundance of species common in the lagoonal zone ${ }^{*}$.

Cross-shelf change accounted for a large percentage of the variability in abundance of all but 1 of 9 species common in the lagoon (Siganus doliatus; Fig. 6). Acanthurus nigrofuscus and Hipposcarus longiceps were significantly more abundant on the outershelf, with no significant differences between the mid-shelf and inshore. A. 'mata' displayed a similar trend but the SNK result was complex (Fig. 6). Scarus brevifilis increased significantly in abundance from inshore to mid-shelf and from mid- to outershelf. $S$. frenatus had a significantly lower abundance inshore, with no significant difference between mid- and outershelf. $S$. globiceps had a significantly lower abundance inshore, also, but the abundance on the mid-shelf was significantly higher than that on the outershelf (Fig. 6). $S$. rivulatus had a significantly lower abundance on the outershelf, with no significant difference between midshelf and inshore. The abundances of Siganus doliatus and Scarus sordidus did not change significantly across the shelf although the SNK analysis for the latter species appears very conservative, considering that it was virtually absent inshore (Fig. 6).

\section{DISCUSSION}

None of the studies of broadscale patterns of distribution and abundance of coral reef fishes on the Great Barrier Reef (Anderson et al., 1981; Williams, 1982, 1983; Williams and Hatcher, 1983) have estimated a within-reef (between-zone) component of variability and compared this with the variability attributed to that between reefs at nearby and widely separated sites. The present study has presented data on the species composition, species richness and abundance of large, herbivorous coral reef fishes at different locations on the continental shelf of the central GBR, at different reefs within each of these locations and at different zones within each of the reefs in two of the locations. Several points can be made from the results. Firstly they confirm the findings of Williams (1982) and Williams and Hatcher (1983) that there are significantly lower numbers of species and individuals of large, herbivorous grazing fishes on reefs inshore than on reefs of the mid- and outer continental shelf. Secondly, herbivorous fishes occur in assemblages which are characteristic of several major zones (windward plus leeward slopes, reef crests plus lagoons, reef flats) and this pattern of zonation is consistent for all 6 mid- and outershelf reefs (Fig. 3).

- Similar figures for reef slope, reef crest, reef flat and back reef zones are available from the author on request
Thirdly, the outershelf reefs have assemblages of herbivorous fishes which are characteristic of the reef slope, reef crest, reef flat, lagoon and back reef and these differ significantly from the corresponding assemblages on mid-shelf reefs (Fig. 3). Thus the study has confirmed that there are significant cross-shelf changes in the assemblages of herbivorous fishes in zones other than the windward reef slope examined by Williams (1982) and Williams and Hatcher (1983). Finally, the results emphasize that a major component of the variability in the species composition and abundance of these fishes is a within-reef (betweenzone) component (Fig. 3). If the mid- and outershelf reefs are considered alone (Russ, 1984), the within-reef (between-zone) component of the variability is far greater than that between locations on the continental shelf and between reefs within these locations.

Williams (1982) observed within-reef variability in the structure of communities of both fishes and corals around the perimeter of many of the reefs included in the present study. He noted that much of this variability was correlated with incident wave energy (see also Done, 1982) and suggested that the changes in the communities around the perimeter of the outershelf reefs were significantly greater than those around the mid-shelf reefs (Williams, 1982). The results of this study are in agreement with these observations. When the windward reef slopes and leeward back reef slopes of both mid- and outershelf reefs are compared, crossshelf difference accounts for the major proportion of the variability (Fig. 3). Furthermore, no differences could be detected between front and back slopes of the mid-shelf reefs (Fig. 3) but a statistically significant difference between front and back reef slopes was recorded for the outershelf reefs.

This degree of similarity between reef slope and back reef zones emphasizes that the major contribution to the within-reef (between-zone) variability in the present study is accounted for by differences between these deep zones and the shallow zones (reef crest, reef flat, lagoon). Several authors have reported distinct differences in the abundance and species composition of, and rates of grazing by, herbivorous fishes at different depths within coral reefs (e.g. Goldman and Talbot, 1976; Bouchon-Navaro and Harmelin-Vivien, 1981; Hay, 1981; Hatcher, 1982; Hatcher and Larkum, 1983; Hay et al., 1983; Hay and Goertemiller, 1983). The shallow zones occur on a gradient of decreasing incident wave energy from reef crest through reef flat to lagoon. Despite the correlation of incident wave energy and the structure of communities of corals (Done, 1982) and assemblages of fishes around the perimeters of the outershelf reefs (Williams, 1982), the assemblages of large, herbivorous reef fishes on the reef crests are more similar to those in the lagoon than 
on the reef flat (Fig. 3). This could be a result of the lagoonal zone including the tops of lagoonal bombies, which have a similar depth and assemblage of corals to that in the reef crest zone. Patterns of zonation of herbivorous grazing fishes within reefs are dealt with in detail in a companion paper (Russ, 1984).
Williams (1982) and Williams and Hatcher (1983), in studies of the windward reef slopes, reported that virtually all the species of coral reef fishes they examined (146 and 323 species, respectively) were unevenly distributed among inshore, mid-shelf and outershelf reefs on the central GBR. The present study has shown that

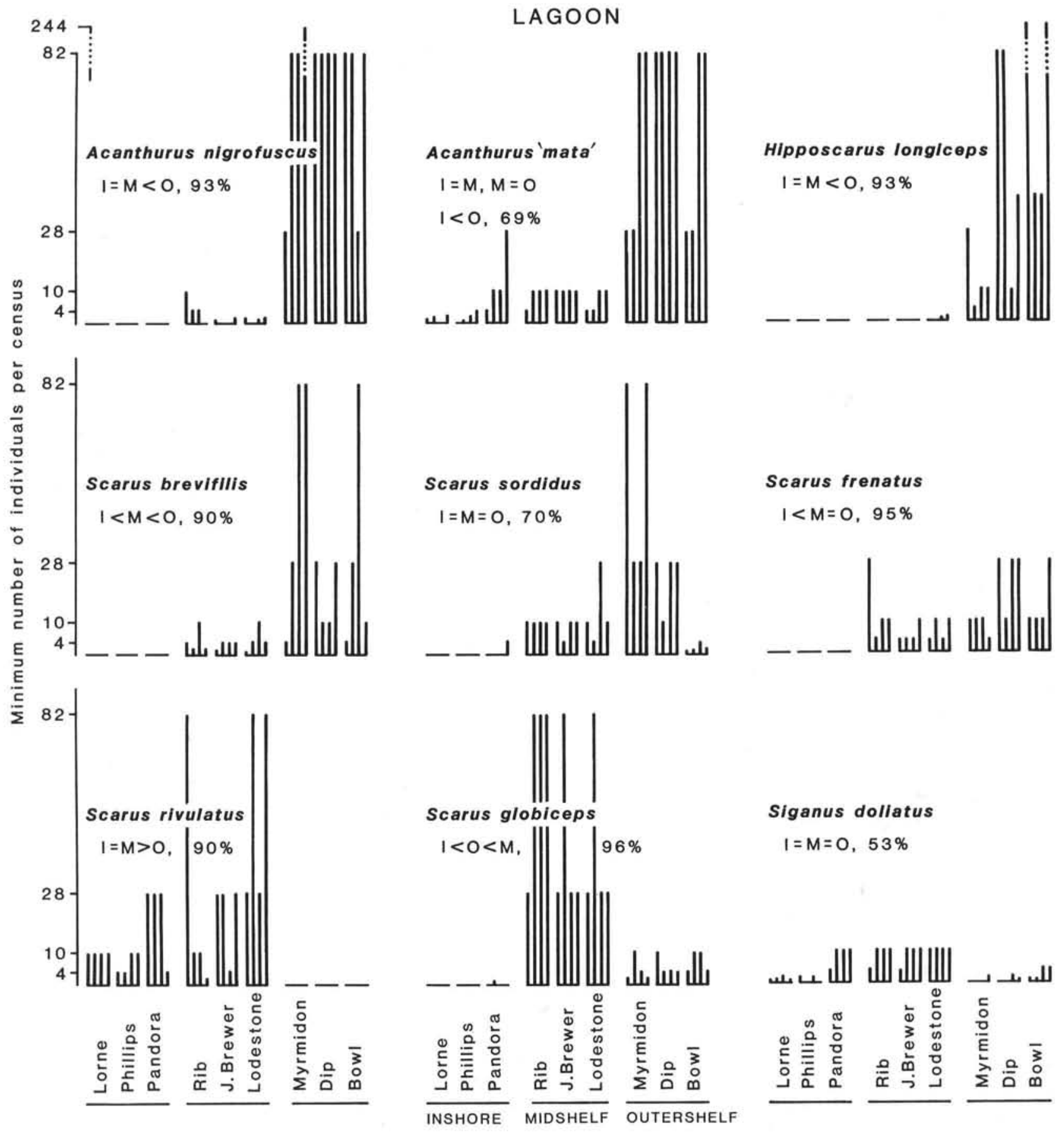

Fig. 6. Cross-shelf change in abundance of 9 species common in the lagoon. Each bar is the minimum number of individuals observed in a census; there were 4 replicate censuses per reef. Results of nested classification 1-factor analyses of variance on the abundance categories summarized as in Fig. 4 
the majority of species of large, herbivorous fishes show significant cross-shelf changes in abundance irrespective of the zone examined (e.g. Fig. 6). For many species much of this variability was accounted for by an absence or low abundance on inshore reefs.

Williams and Hatcher (1983) suggested that the low species richness of fishes on inshore reefs of the central GBR may be due to the different physical and biological environment (e.g. higher turbidity and sediment load, reduced levels of incident light, reduced wave energy and a high abundance of macroalgae on inshore reefs), a reduced supply of larvae, the relatively small size of the inshore reefs or to a lack of zonation and reduced habitat diversity (no reef crest, reef flat, lagoon or reef slope deeper than $13 \mathrm{~m}$ ) or a combination of these factors. Surveys made recently by Williams (1983) have shown that the assemblages of herbivorous fishes on inshore reefs in the far northern GBR (approximately $11^{\circ} \mathrm{S}$ ) are very similar to those on inshore reefs in the present study. These northern reefs are as large or larger than, and structurally zoned in a manner similar to that of the mid- and outershelf reefs off Townsville. It seems unlikely, therefore, that the small size and lack of zonation of the inshore reefs off Townsville account for their low numbers of species and individuals of herbivorous fishes (Williams, pers. comm.). It is of interest that Chave and Eckert (1974) reported a similarly depauperate assemblage of herbivorous fishes in the turbid inner lagoon of Fanning Island relative to the clear outer reef slopes nearby.

Williams and Hatcher (1983) reported also that one of the clearest changes in the abundance of a trophic category of fishes across the continental shelf was a low biomass of algal grazers on the inshore reefs. They suggested that changes in the availability of food to herbivorous fishes across the shelf may be a likely explanation for this pattern. These fishes feed primarily on small, filamentous brown, green and red algae, together with certain species of blue-green algae (e.g. Jones, 1968). These are referred to as algal turfs or the epilithic algal community (Hatcher, 1982). The assemblages of algae on inshore reefs differ considerably from those on mid- and outershelf reefs. There are high standing crops of macroalgae, primarily Sargassum and Turbinaria, inshore. The large thalli of these algae are presumably not very palatable to fishes although Jones (1968) recorded Sargassum as an abundant item in the diet of three species of Naso (Acanthuridae) in Hawaii. One species of Naso only (N. unicornis) was recorded on inshore reefs and was observed rarely. Significantly, the only acanthurids observed commonly on the inshore reefs were 2 species of sand suckers: Acanthurus 'mata' and A. dussumieri. The assemblages of algae on the midand outershelf reefs are primarily highly productive turfs. Russ (in press) presented preliminary data which suggested that there is a greater availability of food on the shallow, windward reef slopes of a mid-and an outershelf reef relative to a similar zone on a reef inshore in the central GBR, due essentially to a higher productivity of turf algae. These results thus suggested a positive correlation between food availability and standing crop of large, herbivorous fishes. This information is consistent with a causal relationship between the availability of algae as food and the abundance of herbivorous fishes. Direct testing of this causal relation would require large scale field experiments in which the abundance of food across the shelf is manipulated and the effect on the abundance of fishes monitored.

The likely proximal factors causing or maintaining differences in community structure of coral reef fishes across the continental shelf in the central region of the Great Barrier Reef have been summarized by Williams and Hatcher (1983). They suggest that the patterns of distribution and abundance could result from: (1) differential availability of larvae across the shelf; (2) patterns of settlement and habitat selection by post-larvae (e.g. in response to food availability, physical factors etc.); (3) differential survivorship after settlement. Differences in the availability of algae may be a proximal factor influencing habitat selection by postlarvae or differential survivorship after settlement. Since it is unlikely, however, that postlarvae can judge the potential productivity of algal turfs in a given area and it seems likely that the cross-shelf patterns are determined prior to, or at the time of, recruitment (Williams, pers. comm.) the availability of algae is more likely to be an ultimate factor determining the distribution and abundance of herbivores. Differences in the availability of food maintained over (evolutionarily) long periods of time may have led to the selection of mechanisms related either to habitat selection or limited dispersal which ensure maximum recruitment of herbivores to mid- and outershelf areas.

Acknowledgements. This study was supported by a Postdoctoral Research Fellowship at the Australian Institute of Marine Science. Discussions with D. Williams, T. Done, A. and B. Hatcher and P. Doherty were particularly useful. D. Barnes, B. Chalker, D. Williams, R. Synnot and M. Hay read and criticized the manuscript. Assistance in the field by several colleagues, particularly Leslie Newman, is gratefully acknowledged. SAHN runs were carried out by H. J. Clay. A. Underwood provided advice on statistical analysis. J. Randall advised on taxonomic nomenclature. Unpublished data on the number of reefs on the GBR was provided by the GBR Marine Park Authority (GBR Gazetteer). M. Thyssen prepared the figures and E. Howlett and K. Truscott typed the manuscript. 


\section{LITERATURE CITED}

Anderson, G. R. V., Ehrlich, A. H., Ehrlich, P. R., Roughgarden, J. D., Russell, B. C., Talbot, F. H. (1981). The community structure of coral reef fishes. Am. Nat. 117: 476-495

Bouchon-Navaro, Y., Harmelin-Vivien, M. L. (1981). Quantitative distribution of herbivorous reef fishes in the Gulf of Aqaba (Red Sea). Mar. Biol. 63: 79-86

Bray, J. R., Curtis, J. T. (1957). An ordination of the upland forest communities of southern Wisconsin. Ecol. Monogr. 27: 325-349

Burr, E. J. (1970). Cluster sorting with mixed character types. II. Fusion strategies. Aust. Comput. J. 1: 98-103

Dinesen, Z. D. (1983). Patterns in the distribution of soft corals across the central Great Barrier Reef. Coral Reefs 1: 229-236

Done, T. J. (1982). Patterns in the distribution of coral communities across the central Great Barrier Reef. Coral Reefs 1: $95-107$

Drew, E. A. (1983). Halimeda biomass, growth rates and sediment generation on reefs in the central Great Barrier Reef Province. Coral Reefs 2: 101-110

Goldman, B., Talbot, F. H. (1976). Aspects of the ecology of coral reef fishes. In: Jones, O. A., Endean, R. (ed.) Biology and geology of coral reefs, Vol. III, Biology, 2. Academic Press, New York, p. 125-154

Hatcher, B. G. (1982). The interaction between grazing organisms and the epilithic algal community of a coral reef: a quantitative assessment. Proc. 4th Int. Coral Reef Symp. 2: $515-524$

Hatcher, B. G. (1983). Grazing in coral reef ecosystems. In: Barnes, D. J. (ed.) Perspectives on coral reefs. Australian Institute of Marine Science, Townsville, Australia, p. 164-179

Hatcher, B. G., Larkum, A. W. D. (1983). An experimental analysis of factors controlling the standing crop of the epilithic algal community on a coral reef. J. exp. mar. Biol. Ecol. 69: 61-84

Hay, M. E. (1981). Spatial patterns of grazing intensity on a Caribbean barrier reef: herbivory and algal distribution. Aquat. Bot. 11: 97-109

Hay, M. E., Colburn, T., Downing, D. (1983). Spatial and temporal patterns in herbivory on a Caribbean fringing reef: the effects on plant distribution. Oecologia (Berl.) 58: 299-308

Hay, M. E., Goertemiller, T. (1983). Between-habitat differ- ences in herbivore impact on Caribbean coral reefs. In: Reake, M. L. (ed.) The ecology of deep and shallow reefs. Symposia series for Undersea Research, Vol. 1. Officer of Undersea Research, NOAA, Rockville, Maryland, p. $97-102$

Jones, R. S. (1968). Ecological relationships in Hawaiian and Johnston Island Acanthuridae (surgeonfishes). Micronescia 4: 309-361

Ogden, J. C., Lobel, P. S. (1978). The role of herbivorous fishes and urchins in coral reef communities. Environ. Biol. Fish. 3: $49-63$

Russ, G. R. (1984). The distribution and abundance of herbivorous grazing fishes in the central Great Barrier Reef. II. Patterns of zonation of mid-shelf and outershelf reefs. Mar. Ecol. Progr. Ser. 20: 35-44

Russ, G. R. (in press). Abundances of herbivorous fishes and measures of food availability across the continental shelf in the central Great Barrier Reef. UNESCO Reports in Marine Science

Sandland, R. L., Young, P. C. (1979a). Probabilistic tests and stopping rules associated with hierarchical classification techniques. Aust. J. Ecol. 4: 399-406

Sandland, R. L., Young, P. C. (1979b). Tables of probabilities associated with the fission of replicate samples in classification. CSIRO Aust. Div. Fish. Oceanogr. Rep. 108

Sokal, R. R., Rohlf, F. J. (1969). Biometry. W. H. Freeman and Co., San Francisco

Williams, D. McB. (1982). Patterns in the distribution of fish communities across the central Great Barrier Reef. Coral Reefs 1: 35-43

Williams, D. McB. (1983). Longitudinal and latitudinal variation in the structure of reef fish communities. In: Baker, J. T. et al. (ed.) Proceedings: Inaugural Great Barrier Reef Conference, Townsville, Aug. 28-Sept. 2, 1983. JCU Press, p. 265-270

Williams, D. McB., Hatcher, A. I. (1983). Structure of fish communities on outer slopes of inshore, mid-shelf and outershelf reefs of the Great Barrier Reef. Mar. Ecol. Prog. Ser. 10: 239-250

Williams, W. T. (1971). Principles of clustering. Ann. Rev. Ecol. Syst. 2: 303-326

Williams, W. T., Lance, G. N. (1977). Hierarchical classificatory methods. In: Enslien, K., Ralston, A., Wilf, W. S. (ed.) Statistical methods for digital computers, Vol. III. Wiley Interscience, New York, p. 269-295

Winer, B. J. (1971). Statistical principles in experimental design, 2nd ed. McGraw-Hill, Kogakusha, Tokyo 